\title{
Financial literacy and personal retirement planning: a socioeconomic approach
}

Financial literacy and retirement planning

Kulondwa Safari

Faculty of Economics and Management, Université Evangélique en Afrique, Bukavu, Congo (the Democratic Republic of The) and Institut pour la Recherche en Statistique Appliquée (IRSA-UEA), Université Evangélique en Afrique, Bukavu, Congo (the Democratic Republic of The) Charity Njoka

Kenyatta University School of Business, Nairobi, Kenya, and Mugisho Guershom Munkwa

Faculty of Economics and Management, Université Evangélique en Afrique, Bukavu, Congo (the Democratic Republic of The)

\begin{abstract}
Purpose - The purpose of this study was to investigate the effect of financial literacy on personal retirement planning in Bukavu city in the Democratic Republic of the Congo (DRC), which is a Sub-Saharan underdeveloped country with a weak pension and social security system.

Design/methodology/approach - This study used a structural equation modeling and a sample of 361 public sector employees selected in Bukavu city in the DRC. The data were collected through a survey questionnaire, and the data were analyzed using SPSS and SMART PLS software.

Findings - The results from the study revealed that financial literacy has a significant impact on personal retirement planning. Two constructs of financial literacy, respectively, computation capability and financial knowledge were found to have a significant impact on personal retirement planning, while financial education and attitudes toward financial products were found not significant in explaining personal retirement planning. Practical implications - The findings from this study can be used by policy makers in the DRC to design socioeconomic programs, aiming to increase the level of financial literacy in the country and awareness on personal retirement planning.

Originality/value - The reviewed studies were based mostly on developed countries, and countries were the social security system works effectively. We have not found a study on financial literacy and retirement planning that has been conducted in the $\mathrm{DRC}$, which is a country with specific characteristics compared to developed countries.
\end{abstract}

Keywords Financial literacy, Personal retirement planning, Structural equation modeling, Democratic republic of the Congo

Paper type Research paper

(C) Kulondwa Safari, Charity Njoka and Mugisho Guershom Munkwa. Published in Journal of Business and Socio-economic Development. Published by Emerald Publishing Limited. This article is published under the Creative Commons Attribution (CC BY 4.0) licence. Anyone may reproduce, distribute, translate and create derivative works of this article (for both commercial and non-commercial purposes), subject to full attribution to the original publication and authors. The full terms of this licence may be seen at http://creativecommons.org/licences/by/4.0/legalcode

The first author is grateful for the generous financial support from Université Evangélique en Afrique that facilitated the data collection.

Conflicts of interest: The authors declare that there is no conflict of interest.
Received 29 April 2021

Revised 1 June 2021

1 July 2021

Accepted 4 July 2021 


\section{JBSED 1,2}

\section{Introduction}

According to the World Bank (2019), in the Democratic Republic of the Congo (DRC), the general literacy rate for adults was estimated to be $77.04 \%$ in 2016 . This indicator measures the number of individuals aged 15 and above who can read and write with understanding a short simple communication about their daily life. However, financial education programs have been inexistent in the country. The government has approved a national financial education program in 2018. This program aims at providing the Congolese population with the financial knowledge that will have a positive effect on their life through improved financial decisions. The implementation of the national financial education is slow, and this could result in poor financial decisions-making among the population. The World Bank is expected to assist the Central Bank of Congo in putting in practice the important measures to ensure the national financial education program is executed (World Bank, 2018).

According to Luzolo (2016), Sub-Saharan Africa is the African zone with the lowest social security coverage rates in the world. The social security coverage is $15.6 \%$, while the global average rate is $40.2 \%$. Social protection systems need to be strengthened in Africa for the benefit of its population. Millions of older Africans people who worked during their active age are in precarious situations with low pensions and need better social security. They are confronted to poor life conditions while they were employed during their working age.

Luzolo (2016) shows that in the DRC, the CNSS (Caisse Nationale de Sécurite Sociale) which is the public institution in charge of collecting workers contributions for retirements offers low retirement benefits. A Congolese retiree receives $1.67 \%$ of his contributions during his entire period of retirement. It is one of the lowest rates in Central Africa and in SubSaharan Africa. The republic of Congo offers 2.5\%, the Gambia 7.5\% and Morocco 6.25\%.

In a study carried out in Bukavu city, the DRC, Cibangala (2019), shows that financial literacy impacts significantly the financial well-being of individuals. Apart from positive social attitudes, individuals that come from a family with a high level of financial literacy are found to have better risk attitudes toward financial plans and financial management. They consider that planning for their projects and for future expenses improve their financial stability and well-being.

Lin et al. (2017) and many other authors demonstrated that financial literacy affects positively retirement planning. The more financially literate an individual is, the more he plans for his retirement. While the population is waiting for the implementation of the national financial education program, it is important to explore the effect of financial literacy on personal retirement planning among public sector employees in the DRC.

This study intends to investigate whether financial literacy affect retirement planning decisions among public sector employees in DRC.

The present study proceeds as follows: the first section presents the literature review, the second section presents the methodology and the last section presents the research findings.

\section{Literature review \\ Theoretical review}

This section presents the theory of life cycle that is the underpinned theory of this research.

Life cycle theory. Life cycle theory was introduced by the Modigliani through two research papers published in the 1950. The theory postulated that people make informed choices about the amount to allocate for expenses for each period of their life. However, these decisions are limited by the availability of resources that individuals can access during their life. By building up and running down assets, employees can make financial plans for their retirement and adapt their expenses to their needs at each stage of their living years. The life cycle story is the one in which the resource of the country circulate; the young individuals have few resources, the middle-aged individuals have more and the highest level of wealth is possessed by individuals who are about to retire. Through their retirement period, retirees sell off their assets to get food, accommodation and entertainment (Deaton, 2005). 
Blau and Blau (2007) show that during the retirement period, consumption expenses are reduced in households, and life cycle theory can explain that situation. Bodie et al. (2007) emphasize that decisions such as the allocation of portfolios for retirement investments and the subscription to a retirement insurance plan are guided by the life cycle theory. The present study intends to test whether during the age before the retirement period individuals change their retirement planning behavior in DRC based on the life cycle theory.

\section{Empirical review}

This section presents the previous studies which investigated the relationship between financial literacy and retirement investments.

Financial knowledge and retirement planning. Rooij et al., 2011 assessed the impact of financial literacy on retirement preparedness in the Netherlands. This study examined how financial knowledge impacts retirement preparedness in the Netherlands. Multivariate ordinary least square was applied, and the results revealed that financial knowledge affect significantly retirement planning; therefore, individuals with high financial knowledge have a high probability to plan for retirement. The research is based on Netherlands. The current research is centered on the DRC.

Arrondel (2013) assesses the relationship between financial literacy and financial planning in France. Using ordinary least square, the author find out that some subpopulations have low degree of financial literacy compared to others, women, young, old and people with low degree of education have a low degree of financial knowledge. The differences in financial knowledge were found to be associated with retirement planning. The current study is based on the DRC, unlike the previous study which is based on France.

Bongini et al. (2019) study university students' involvement in retirement planning. The aim of the study is to explore the factors predicting university student to have intentions to invest in a pension funds. The theory of planned behavior and ordinary least square stepwise multiple regression analysis is used. The results reveal that theory of planned behavior predictors, pension knowledge and money management influence positively the intention to invest in a pension fund. However, this research includes only youth in the sample; the current study included individuals who are close to the retirement period in the DRC.

H1. The level of financial knowledge influences personal retirement planning among public sector workers in Bukavu city, the Democratic Republic of the Congo

Computation capability and retirement investment. Klapper et al. (2011) examine the link between financial literacy and retirement planning in Russia. Using a probit model, the results revealed that only $36 \%$ of respondents who have computational capability plans for their retirement. These individuals could understand interest compounding and inflation. Financial literacy was proved to have a significant effect on retirement planning and pension funds participation. However, this study is centered on retirement planning and pension funds participation in Russia. In addressing this gap, the current study focuses on an underdeveloped country, the DRC and includes three main constructs of financial literacy: financial education, financial knowledge and computation capability.

Anderson et al. (2017) investigate the relationship between precautionary savings, retirement preparedness and misperceptions of financial literacy. LinkedIn members were surveyed, and questions were asked to assess the level of computation capability. The probit model was applied, and results reveals that computation capability as a construct of financial literacy and planning for retirement were found to be positively correlated. Individuals who have a good command in computation are more likely to make plans for their retirement. However, this study is based on employees selected on Linkedin without differentiating the 
JBSED

1,2

124 sector of employment. The present study addresses this gap in investigating the case of public sector employees.

Sekita (2015) explores the impact of financial literacy on retirement planning in Japan. The purpose of this study is to do an assessment of the level of financial literacy in Japan, to determine which group in Japan has a low level of financial literacy and to determine the link between financial literacy and retirement planning. A multivariate analysis, a simple linear probability model regression were used to determine the relationship between financial literacy and retirement planning as well as socioeconomic characteristics. The results revealed that individuals who had a good computation capability of interests and inflation are more likely to have a saving plan for retirement. The lowest degree of financial literacy was observed among women, the young and people with a low income and a low degree of education. The research was based on Japan, thus the current study fills that gap in studying financial literacy and retirement planning in the DRC.

Lusardi et al. (2011) studied the effect of financial literacy on retirement preparedness in the United States. The authors used a multivariate model, an ordinary least squares regression and find out that individuals with high score of financial literacy are the ones who plans for retirement. In a set of measures of financial literacy, a good level of computation capability of inflation and interests are find to have a positive impact on retirement planning. However, this study is centered on the United States of America; the present study fills that gap in carrying out an investigation on DRC.

H2. Computation capability has an influence on retirement investment of public sector workers in Bukavu city, the Democratic Republic of the Congo.

Financial education and retirement investment. Folk et al. (2012) investigate the impact of financial education on retirement financial planning. The author used a sample of 404 individuals in the preretirement period and hierarchical regression analysis. The results from the study reveal that financial education have a significant impact on financial retirement planning. Individuals who attend financial education programs are found to adopt a planning behavior and are more interested in preparing a future financial well-being. However, the study was based on Malaysia. In addressing the research gap, the current study is based on the DRC.

The study of Lusardi and Mitchelli (2007) analyzes the factors behind lack of retirement preparedness in the United States of America. Financial literacy was tested in the study as a factor that can hinder retirement planning. While a large interests have been showed by nonprofits organizations and governments to enhance financial literacy level, the study reveals that financial literacy have a positive effect on retirement savings. The more an individual is financially literate, the more he constitutes savings for his retirement expenses. However, this study focuses only on the factors that hinder retirement planning. The current study fills that gap in investigating factors that increase or decrease the probability to plan for retirement.

Clark et al. (2003) analyze the effect of financial education on retirement savings. The author investigates a group of individuals in two surveys carried out before and after attainment of a financial education program. The finding from the study reveals that after attending a financial education event, individuals are more likely to change their retirement saving plans. They are more interested in finding out the available means that can be used to save for the retirement. However, this study is limited to retirement savings. This gap is addressed in the current empirical study in including also retirement investments.

Ntalianis and Wise (2011) explore the impact of financial education on retirement planning. The study shows that governments do not have the capacity to offer enough retirement income in many countries, and access to financial education have a positive impact on retirement planning. Attending seminars, receiving written communications and online information are found to be effective methods to access financial education. 
Recommendations from the study state that individuals should make efforts to access financial education for a better retirement planning. This study is limited to financial education. The present study includes financial knowledge and computation capability to explain retirement planning.

In the United States of America, Lusardi and Mitchell (2017) investigates the impact of financial literacy on retirement preparedness. Using the American life panel measures of financial literacy, the results prove that financial knowledge acquired in schools before entering the labor market has a positive effect on planning for the retirement. It is therefore important to design education programs for youths as a way to equip them with the necessary financial knowledge that will impact positively their financial well-being later in their retirement. However this study is centered on the United States of America. The present study aimed at filling this gap in studying the case of an under developed country, the DRC.

H3. Financial education influences personal retirement planning among public sector employees in Bukavu city, the Democratic Republic of the Congo.

Risk attitudes toward financial products and retirement investment. Dummann (2008) investigates the relationship between retirement saving and attitudes toward financial intermediaries in Germany. Using a life cycle hypothesis, the findings from the study show that attitudes toward financial intermediaries and products have a significant effect on retirement saving. Subscribing to life insurance products is influenced by household risk attitudes toward financial products. Individuals avoid risky investments because they expect to lose a significant amount of money. A low level of risk aversion is positively associated with old age savings behavior. However, this study is limited to retirement savings. The present study addresses this gap in verifying how attitudes toward financial products affect personal retirement planning.

Satria and Hutabarat (2020) explore the effect of financial literacy on financial planning for retirement using a sample of 120 university lecturers selected in Indonesia. To achieve the purpose of the research, a linear regression model was applied to test the relationships. The results from the study show that attitudes toward retirement products are significant in making personal plans for the retirement. Individuals with positive attitudes toward retirement products are more likely to make pension financial plans. This study focuses on university lecturers who are individuals with high education levels and who are more likely to be financially literate. This gap was filled in the present study that was based on public sector employees from many domains.

Meir et al. (2016) analyze the effect of financial literacy and retirement planning in Israel. An online survey was conducted on 501 Israelis randomly, and multiple ordinary least square regressions were applied. Results show that individuals with low risk aversion toward retirement products are more likely to plan for their retirement. An individual's risk aversion attitude is proved determine financial decisions such as retirement saving options and retirement investment options. This study did not show the differences of risk attitudes depending on the age of individuals. The present research addresses that gap in investigating retirement plans in the preretirement period.

H4. Risk attitudes toward financial products influences personal retirement planning among public sector workers in Bukavu city, the Democratic Republic of the Congo.

\section{Methodology}

\section{Introduction}

This section presents subsequently our research design, data collection procedure, and the operationalization and measurement of variables.

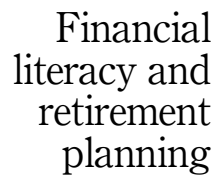

125 
JBSED

1,2

Research design

This section presents the empirical model used, the population as well as the process of collecting data.

\section{Empirical model}

Many variables are associated with retirement investments. However, these variables are not observed in isolation, and so it is useful to be able to carry out a multivariate analysis to understand the full picture. In this study, the measurement of financial investments chosen is behavioral due to the fact that people do not like to disclose the exact amount invested. This fact drives this study to adopt a behavioral approach and hence give a latent nature to our dependent variables.

Referring to the studies of Jime (2018) and (Katoroogo, 2016), structural equation modeling approach will be used to get the results for the present research. During the past years, behavioral finance researchers have increased their interest in the application of structural equation modeling (SEM). Historically, the research areas where multivariate techniques have been used were the behavioral and biological sciences. Nowadays, interest in multivariate methods has now expanded to many other fields of research among others business and finance (Alvin, 1995). SEM is a concept utilized to describe a growing and increasingly general set of statistical methods for modeling data. The biggest strength of SEM is its capacity to model links between latent variables; these are the unobserved constructs of which observed variables may be for them misrepresentative.

\section{Empirical model formulation and measurement}

We have selected two variables (constructs) to measure personal retirement planning, these are savings and assets.

$$
\mathrm{PRP}=\mathrm{FN} \beta_{1}+\mathrm{CP} \beta_{2}+\mathrm{FE} \beta_{3}+\mathrm{ATFP} \beta_{4}+e_{i}
$$

where:

$$
\begin{aligned}
& \mathrm{PRP}=\text { Personal retirement planning } \\
& \mathrm{FN}=\text { Financial knowledge } \\
& \mathrm{CP}=\text { Computation capability } \\
& \mathrm{FE}=\text { Financial education }
\end{aligned}
$$

ATFP $=$ Attitudes toward financial products (see Figure 1).

\section{Data collection procedure}

A sample size of 361 individuals was purposively selected. The necessary data were collected through a survey questionnaire that had two parts; the first part had questions on the socioeconomic profile of respondents, while the second section had items questions on retirement planning and financial literacy constructs. Survey questionnaire were submitted to respondents at their work place by a team of enumerators hired and trained for that purpose. Enumerators used a recommendation letters issued by Université Evangélique in the offices of different public institutions to request interviews with workers.

\section{Operationalization and measurement of variables}

The table below describes the different variables selected for this study (see Table 1). 


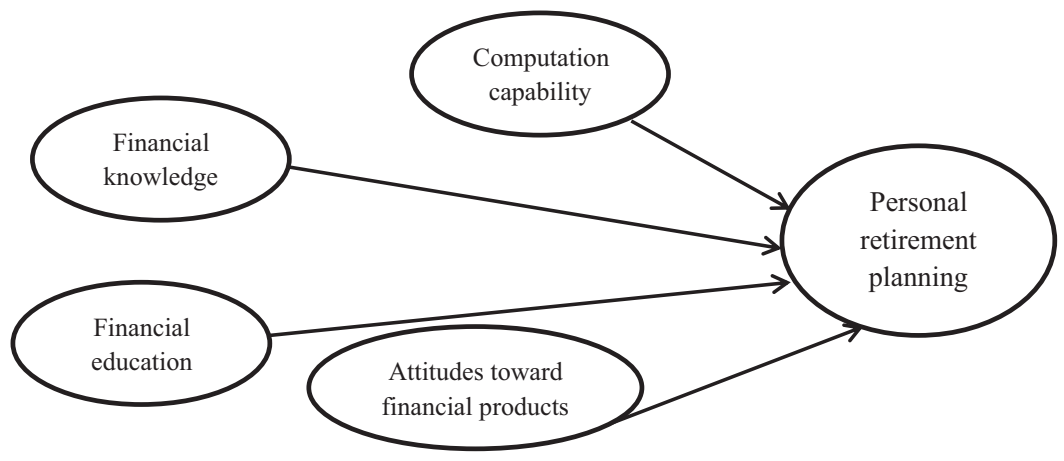

Financial literacy and retirement planning

Figure 1.

Research framework

\begin{tabular}{|c|c|c|c|c|c|}
\hline Category & Variable type & Indicators & Empirical studies & Measurement & \\
\hline $\begin{array}{l}\text { Dependent } \\
\text { variable }\end{array}$ & $\begin{array}{l}\text { Personal } \\
\text { retirement } \\
\text { planning }\end{array}$ & $\begin{array}{l}\text { Several items constructs } \\
\text { on investments and } \\
\text { savings for retirement } \\
\text { purposes }\end{array}$ & $\begin{array}{l}\text { Jime (2018), Klapper } \\
\text { et al. (2011), Ntalianis } \\
\text { and Wise (2011) }\end{array}$ & $\begin{array}{l}\text { Ordinal } \\
\text { Likert scale }\end{array}$ & \\
\hline \multirow{5}{*}{$\begin{array}{l}\text { Independent } \\
\text { variables }\end{array}$} & Financial literacy & & & & \\
\hline & $\begin{array}{l}\text { Financial } \\
\text { knowledge }\end{array}$ & Several items constructs & $\begin{array}{l}\text { Arrondel (2013), } \\
\text { Bongini et al. (2019) }\end{array}$ & $\begin{array}{l}\text { Ordinal } \\
\text { Likert scale }\end{array}$ & \\
\hline & $\begin{array}{l}\text { Computation } \\
\text { capability }\end{array}$ & Several items constructs & $\begin{array}{l}\text { Klapper et al. (2011), } \\
\text { Anderson et al. (2017), } \\
\text { Rooij et al. (2011) }\end{array}$ & $\begin{array}{l}\text { Ordinal } \\
\text { Likert scale }\end{array}$ & \\
\hline & $\begin{array}{l}\text { Financial } \\
\text { education }\end{array}$ & Several items constructs & $\begin{array}{l}\text { Lusardi and Mitchell } \\
\text { (2017), Ntalianis and } \\
\text { Wise (2011) }\end{array}$ & $\begin{array}{l}\text { Ordinal } \\
\text { Likert scale }\end{array}$ & \\
\hline & $\begin{array}{l}\text { Attitudes toward } \\
\text { financial products }\end{array}$ & Several items constructs & $\begin{array}{l}\text { Dummann (2008), } \\
\text { Satria and Hutabarat } \\
\text { (2020), Meir et al. } \\
(2016)\end{array}$ & $\begin{array}{l}\text { Ordinal } \\
\text { Likert scale }\end{array}$ & $\begin{array}{r}\text { Table 1. } \\
\text { Operationalization and } \\
\text { measurement of } \\
\text { Variables }\end{array}$ \\
\hline
\end{tabular}

\section{Research findings}

Socioeconomic characteristics of respondents

This section presents the characteristics of the study respondents.

The results in Table 2 show that most respondents were aged between 50 and 60 years $(60.4 \%)$ and the rest $(39.6 \%)$ is constituted by individuals aged between 60 and 65 years This shows that most of the respondents are in the period close to the retirement age which is 65 years in the Democratic Republic of the Congo. The majority of the study respondents were male $(83.9 \%)$, Females represented $16.1 \%$ of respondents. Married individuals constitute the majority of the study respondents $(90.3 \%)$, and divorced represent the minority of or respondents $(3 \%)$. The majority of the study respondents are educated, $69.0 \%$ have a bachelor degree and $21 \%$ have a high school level. This can be explained that the respondents are constituted with public sector workers, and one of the requirements to work for the public sector is to hold a school degree or certificate. The results show that for the majority of the study respondents $(60.7 \%)$ their earnings are below 3,60,000 Congolese Francs, and only the minority have a salary above 36,00,000 Congolese Francs. 


\begin{tabular}{|c|c|c|c|}
\hline \multirow{6}{*}{$\begin{array}{l}\text { JBSED } \\
1,2\end{array}$} & & & \\
\hline & & Frequency & Percent \\
\hline & Age & & \\
\hline & $50-60$ & 218 & 60.4 \\
\hline & $61-65$ & 143 & 39.6 \\
\hline & Total & 361 & 100.0 \\
\hline \multirow{22}{*}{128} & Gender & & \\
\hline & Female & $\begin{array}{r}58 \\
303\end{array}$ & 16.1 \\
\hline & $\begin{array}{l}\text { Male } \\
\text { Total }\end{array}$ & $\begin{array}{l}303 \\
361\end{array}$ & $\begin{array}{r}83.9 \\
100.0\end{array}$ \\
\hline & Marital status & & \\
\hline & Divorced & 11 & 3.0 \\
\hline & Married & 326 & 90.3 \\
\hline & Separated & 12 & 3.3 \\
\hline & Single & 12 & 3.3 \\
\hline & Total & 361 & 100.0 \\
\hline & Education level & & \\
\hline & Bachelor & 249 & 69.0 \\
\hline & Certificate & 3 & 0.8 \\
\hline & High school & 77 & 21.3 \\
\hline & Masters & 12 & 3.3 \\
\hline & Never been to formal school & 4 & 1.1 \\
\hline & Phd & 8 & 2.2 \\
\hline & Primary school & 8 & 2.2 \\
\hline & Total & 361 & 100.0 \\
\hline & Income of respondents & & \\
\hline & Below 360000 & 219 & 60.7 \\
\hline & Between 1800001 and 3600000 & 8 & 2.2 \\
\hline & Between 360000 and 900000 & 103 & 28.5 \\
\hline \multirow{3}{*}{$\begin{array}{l}\text { Table } 2 \text {. } \\
\text { Socioeconomic profile } \\
\text { of respondents }\end{array}$} & Between 900001 and 1800000 & 27 & 7.5 \\
\hline & More than 3600000 & 4 & 1.1 \\
\hline & Total & 361 & 100.0 \\
\hline
\end{tabular}

Descriptive statistics of the study variables

This section presents the descriptive statistics of the latent variables used in this study which have items measured by a Likert scale as follows: 1 . strongly disagree, 2 . disagree, 3 . neither agree nor disagree, 4 . agree and 5 . strongly agree.

The results in Table 3 show that in average, the majority of the study respondents have positive attitudes toward personal retirement planning or have invested or saved for retirement purposes a (With mean $=4.16$ ). The majority of public sector employees in Bukavu city, DRC have a low level of financial knowledge with all the items related to financial knowledge with an average of 3.25 which is below 4 . The majority of respondents disagreed (Average below 3 ) on questions related to computation capability; this shows that the level of computation capability of public sector employees in Bukavu city, DRC is low. Most of respondents disagreed on questions related to financial education showing that the level of financial education of public sector employees is low (Average below 3) in Bukavu city, DRC. There is a need to promote financial education programs for the profit of the population of DRC. The level of knowledge of financial products is low (Average below 3) among public sector employees in Bukavu city, DRC. This situation should be improved by financial education programs in order to enable individuals to make sound financial decisions, for instance to make financial plans for retirement purposes. 


\begin{tabular}{|c|c|c|c|c|c|}
\hline & $N$ & Minimum & Maximum & Mean & Financial \\
\hline $\begin{array}{l}\text { Personal retirement planning } \\
\text { Itema1 } \\
\text { Itema2 } \\
\text { Itema3 } \\
\text { Itema4 } \\
\text { Personal retirement planning }\end{array}$ & $\begin{array}{l}361 \\
361 \\
361 \\
361\end{array}$ & $\begin{array}{l}1 \\
1 \\
1 \\
1\end{array}$ & $\begin{array}{l}5 \\
5 \\
5 \\
5\end{array}$ & $\begin{array}{l}4.29 \\
3.99 \\
4.40 \\
3.96 \\
4.16\end{array}$ & $\begin{array}{r}\text { retirement } \\
\text { planning } \\
\mathbf{1 2 9}\end{array}$ \\
\hline $\begin{array}{l}\text { Financial knowledge } \\
\text { Item1 } \\
\text { Item2 } \\
\text { Item3 } \\
\text { Item4 } \\
\text { Item5 } \\
\text { Financial knowledge }\end{array}$ & $\begin{array}{l}361 \\
361 \\
361 \\
361 \\
361\end{array}$ & $\begin{array}{l}1 \\
1 \\
1 \\
1 \\
1\end{array}$ & $\begin{array}{l}5 \\
5 \\
5 \\
5 \\
5\end{array}$ & $\begin{array}{l}3.14 \\
3.21 \\
3.15 \\
3.23 \\
3.25 \\
3.25\end{array}$ & \\
\hline $\begin{array}{l}\text { Computation capability } \\
\text { Item6 } \\
\text { Item7 } \\
\text { Item8 } \\
\text { Item9 } \\
\text { Item10 } \\
\text { Computation capability }\end{array}$ & $\begin{array}{l}361 \\
361 \\
361 \\
361 \\
361\end{array}$ & $\begin{array}{l}1 \\
1 \\
1 \\
1 \\
1\end{array}$ & $\begin{array}{l}5 \\
5 \\
5 \\
5 \\
5\end{array}$ & $\begin{array}{l}2.70 \\
2.35 \\
2.50 \\
2.40 \\
2.28 \\
2.446\end{array}$ & \\
\hline $\begin{array}{l}\text { Financial education } \\
\text { Item11 } \\
\text { Item12 } \\
\text { item13 } \\
\text { Financial education }\end{array}$ & $\begin{array}{l}361 \\
361 \\
361 \\
361\end{array}$ & $\begin{array}{l}1 \\
1 \\
1\end{array}$ & $\begin{array}{l}5 \\
5 \\
5\end{array}$ & $\begin{array}{l}2.59 \\
2.25 \\
2.71 \\
2.51\end{array}$ & \\
\hline $\begin{array}{l}\text { Attitudes toward financial products } \\
\text { Item14 } \\
\text { Item15 } \\
\text { Item16 } \\
\text { Item17 } \\
\text { Attitudes toward financial products }\end{array}$ & $\begin{array}{l}361 \\
361 \\
361 \\
361\end{array}$ & $\begin{array}{l}1 \\
1 \\
1 \\
1\end{array}$ & $\begin{array}{l}5 \\
5 \\
5 \\
5\end{array}$ & $\begin{array}{l}2.59 \\
2.23 \\
2.68 \\
3.24 \\
2.68\end{array}$ & $\begin{array}{r}\text { Table } 3 . \\
\text { Descriptive statistics of } \\
\text { the study variables }\end{array}$ \\
\hline
\end{tabular}

\section{Structural equation modeling results}

This section presents the steps followed to estimates and to validate the final structural equation model used to respond to the research hypothesis.

Internal consistency and reliability tests

Individual reliability is measured by the outer loadings for each item used in constructs. Referring to (Hair et al., 2012), the value of the outer loading should be over 0.70 for the item to be retained.

In the present research, Cronbach's alpha and composite reliability were used to test the consistency and reliability of the dependent and independent variables (represented by constructs). Referring to Risher, 2018, constructs with Cronbach's alpha or composite reliability between 0.70 and 0.60 meet the internal consistency reliability.

The results in Table 4 show the retained items after removing the items that did not meet the threshold of internal consistency in the first estimated model.

After our fist estimations, the variable financial education and attitudes toward financial products were removed for not passing the consistency and reliability test. The results in 
JBSED

1,2

130

Table 5 show that two constructs out of four constructs for financial literacy as well as the variable personal retirement planning were retained for the final model estimation. Personal retirement planning, financial knowledge and computation capability have passed the consistency and reliability test with values of Cronbach's alpha and composite reliability over 0.7.

\section{Convergent validity, discriminant validity and correlations}

The present research used the Fornell-Larcker criterion to assess the discriminant validity. Referring to (Fornell and Larcker, 2016), the square root of AVE (average variance extracted) should be minimum 0.50 and should be higher than the correlations between the selected latent variables. The results in Table 6 show that the convergent validity of the constructs is adequate because the square roots of AVE displayed on the diagonals are above the correlations displayed off-diagonals, and the correlations off-diagonals are low implying a low risk of multi-collinearity.

\section{Estimated structural equations using bootstrapping}

After completing the preliminary tests, the final model was estimated using bootstrapping. The findings in Table 7 displays the final estimated model that included two variables out of the four

\begin{tabular}{lccc}
\hline & Computation capability & Financial knowledge & Personal retirement planning \\
\hline Item1 & & 0.773 & \\
Item2 & & 0.800 & \\
Item4 & & 0.729 & \\
Item5 & 0.847 & 0.860 & \\
Item6 & 0.923 & & 0.899 \\
Item8 & & & 0.931 \\
Itema2 & & & \\
Itema4 & & & \\
\end{tabular}

Table 4.

Outer loadings

\begin{tabular}{lccc}
\hline & $\begin{array}{c}\text { Cronbach's } \\
\text { alpha }\end{array}$ & $\begin{array}{c}\text { Composite } \\
\text { reliability }\end{array}$ & $\begin{array}{c}\text { Average variance extracted } \\
\text { (AVE) }\end{array}$ \\
\hline Computation capability & 0.732 & 0.879 & 0.785 \\
$\begin{array}{l}\text { Financial knowledge } \\
\text { Personal retirement } \\
\text { planning }\end{array}$ & 0.814 & 0.870 & 0.627 \\
& 0.808 & 0.912 & 0.838 \\
\hline
\end{tabular}

Table 6.

Discriminant validity (Fornell-Larcker criterion)

\begin{tabular}{lccc}
\hline & $\begin{array}{c}\text { Computation } \\
\text { capability }\end{array}$ & $\begin{array}{c}\text { Financial } \\
\text { knowledge }\end{array}$ & $\begin{array}{c}\text { Personal retirement } \\
\text { planning }\end{array}$ \\
\hline Computation capability & 0.886 & & \\
Financial knowledge & 0.373 & 0.792 & \\
Personal retirement & 0.281 & 0.389 & 0.915
\end{tabular}
planning

Note(s): Values on the diagonal represent the square root of the AVE, while the off-diagonals represent correlations 
selected in the model design. The two variables (computation capability and financial knowledge) included in the final estimated model are significant with $p$-values (respectively 0.025 and 0.000$)$ below the significant level of $0.05(5 \%)$. These results imply that two constructs of financial literacy namely computation capability and financial knowledge have a positive impact on personal retirement planning; hence, the $\mathrm{H} 2$, H3 are accepted. Therefore, increasing the level of knowledge of financial instruments and investment options, the level of computation capability related to interest on savings, credits, investments and retirement benefits has a positive impact on personal retirement planning. On the one hand, these results are in line with the study of (Arrondel, 2013) (Rooij et al., 2011) conducted, respectively, in France and Netherlands and that proved that financial knowledge has a positive effect on retirement planning. On the other hand, the findings from the present study concur with the results from the research of Klapper, 2011, Anderson et al., 2017, Sekita, 2015 and Lusardi et al., 2011 conducted, respectively, in Russia, on Linkedin, in Japan and USA, respectively, and that showed that computation capability influences retirement planning. The findings from this study concur with the results from the study of Safari and Njoka, 2021 that used logistic regression analysis and that was based on the same dataset with the present study (see Figure 2).

\section{Predictive power test and model fit test}

The results in Table 8 show that the significant independent variables in the estimated model explain $16.8 \%$ of the changes in retirement planning decisions among public sector employees in Bukavu city in the DRC. The good of fit index (Gof) was used to assess the

\begin{tabular}{|c|c|c|c|c|c|c|}
\hline & $\begin{array}{l}\text { Original } \\
\text { sample }(O)\end{array}$ & $\begin{array}{l}\text { Sample } \\
\text { mean }(\mathrm{M})\end{array}$ & $\begin{array}{c}\text { SD } \\
\text { (STDEV) }\end{array}$ & $\begin{array}{l}\text { T statistics }(\mid \mathrm{O} / \\
\text { STDEV } \mid)\end{array}$ & $\begin{array}{c}p- \\
\text { values }\end{array}$ & \\
\hline $\begin{array}{l}\text { Computation capability } \rightarrow \text { personal } \\
\text { retirement planning }\end{array}$ & 0.158 & 0.164 & 0.070 & 2.241 & 0.025 & \\
\hline $\begin{array}{l}\text { Financial knowledge } \rightarrow \text { personal } \\
\text { retirement planning }\end{array}$ & 0.330 & 0.332 & 0.066 & 4.976 & 0.000 & $\begin{array}{r}\text { Results of the } \\
\text { hypothesis testing }\end{array}$ \\
\hline
\end{tabular}

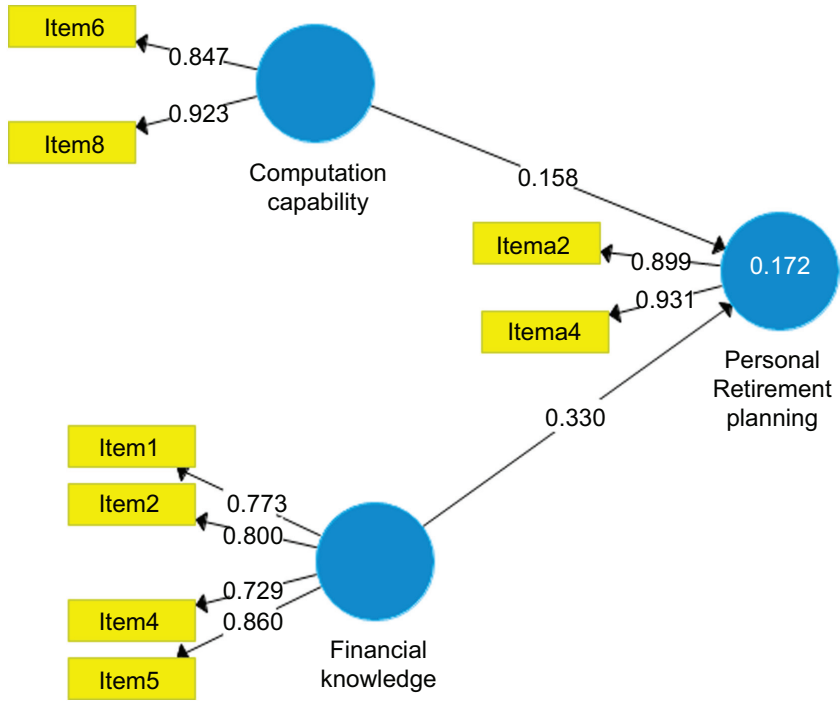

Figure 2.

Structural equation estimates 


\begin{tabular}{|c|c|c|c|}
\hline \multirow[t]{3}{*}{$\begin{array}{l}1,2 \\
1,2\end{array}$} & & $R$ square & $R$ square adjusted \\
\hline & Personal retirement planning & 0.172 & 0.168 \\
\hline & $\begin{array}{l}\text { Model fit test } \\
\text { Constructs } \\
\text { Personal financial retirement } \\
\text { Computation capability }\end{array}$ & $\begin{array}{c}\text { Average variance extracted ( } A V E) \\
0.838 \\
0.785\end{array}$ & $\begin{array}{c}R^{2} \\
0.172\end{array}$ \\
\hline $\begin{array}{l}\text { Table } 8 \text {. } \\
\text { Predictive power test } \\
\text { and Model fit test }\end{array}$ & $\begin{array}{l}\text { Financial knowledge } \\
\text { Average score } \\
\text { Average* } R^{2} \\
\mathrm{GOF}=\left(\mathrm{AVE}^{*} R^{2}\right)^{1 / 2}\end{array}$ & $\begin{array}{c}0.627 \\
0.75 \\
0.129 \\
0.36\end{array}$ & \\
\hline
\end{tabular}

fitness of the estimated model. Based on the study of Haron and Aziz, 2019, the Gof index is between 0 and 1 . When the $\mathrm{GoF}$ index equals 0.10 , it is regarded as small, while when the $\mathrm{GoF}$ index equals 0.25 and 0.36 , it is regarded as medium and large respectively. The results show that our estimated model generated a GoF index of 0.36 that indicate a large goodness of fit for the estimated model.

\section{Conclusion and recommandations}

The DRC is among countries that offer low retirement benefits; the present research aimed to investigate the effect of financial literacy on personal retirement planning in the DRC. The exploration of the empirical review led to the formulation of the hypothesis that financial knowledge, computation capability, financial education and attitudes toward financial products are the constructs of financial literacy that are more likely to influence personal retirement planning. An analysis of the data collected through a survey conducted in public sector institutions in Bukavu city in the DRC through structural equation modeling led to the findings that showed that computation capability and financial knowledge are the factors that determine personal retirement planning among public sector workers in Bukavu city, the DRC.

Employee's syndicates of the DRC should increase awareness on the advantages of personal retirement planning. In its socioeconomic development programs, the government of the DRC should set up financial education programs for the benefit of the population. The World Bank should accelerate the process of the implementation of its financial education program for the DRC.

Future research orientations in line with this study can be formulated in two directions. In the one hand, the issue of personal retirement planning in the DRC should be further investigated by future research in studying the burden of retirees on the government and the society. In the other hand, it is important to understand how retirees will affect the economy of DRC in the coming years given that the country has a large population size. The socioeconomic impact of the lack of personal retirement planning among retirees should also be investigated.

\section{References}

Alvin, C.R. (1995), Methods of Multivariate Analysis, John Willey \& Sons.

Anderson, A., Baker, F. and Robinson, D.T. (2017), "Precautionary savings, retirement planning and misperceptions of financial literacy", Journal of Financial Economics, Elsevier B.V., Vol. 126 No. 2, pp. 383-398, doi: 10.1016/j.jfineco.2017.07.008.

Arrondel, L. (2013), "Financial literacy and financial planning in France financial literacy and financial planning in France", Vol. 6 No. 2. 
Blau, D.M. and Blau, D.M. (2007), "Retirement and consumption in a life cycle model", No. 2986.

Bodie, Z., Treussard, J. and Willen, P. (2007), "The theory of life - cycle saving and investing”, No. 7.

Bongini, P., Cucinelli, D. and Bongini, P. (2019), "University students and retirement planning: never too early", doi: 10.1108/IJBM-03-2018-0066.

Cibangala, P.B. (2019), “Education Financière des ménages : développement et validation d' une échelle de mesure", pp. 1-48.

Clark, R.L., Ambrosio, M.B. and Mcdermed, A.A. (2003), Financial Education and Retirement Savings.

Deaton, A. (2005), "Franco Modigliani and the life-cycle theory of consumption", BNL Quarterly Review, Vol. LVIII September, pp. 91-107.

Dummann, K. (2008), "Retirement saving and attitude towards financial intermediaries: evidence for Germany (No. 99)", Thünen-Series of Applied Economic Theory-Working Paper.

Folk, J.Y., Beh, L.S. and Baranovich, D. (2012), "Financial education: determinant of retirement planning in Malaysia”, Vol. 3 No. 2, pp. 69-78.

Fornell, C. and Larcker, D.F. (2016), "Evaluating structural equation models with unobservable variables and measurement", Vol. 18 No. 1, pp. 39-50.

Hair, J.F., Ringle, C.M. and Sarstedt, M. (2012), "An assessment of the use of partial least squares structural equation modeling in marketing research", pp. 414-433, doi: 10.1007/s11747-0110261-6.

Haron, R. and Aziz, S. (2019), "Predicting small and medium-sized adoption of financial technology in Islamic crowd-funding”, September. doi: 10.4018/978-1-7998-0039-2.ch002.

Jime, I. (2018), "Too soon to worry? Longitudinal examination of financial planning for retirement among Spanish aged workers", pp. 1-18.

Katoroogo, R.M. (2016), "Behavioural determinants of financial inclusion in Uganda", No. 939600.

Klapper, L. (2011), Financial Literacy and Retirement Planning in View of a Growing Youth Demographic Growing Youth Demographic: The Russian Case.

Klapper, L., Panos, G.A. and Klapper, L. (2011), "Of Pension Economics and Finance : financial literacy and retirement planning: the Russian case Financial literacy and retirement planning: the Russian case *”, pp. 599-618, doi: 10.1017/S1474747211000503.

Lin, C., Hsiao, Y. and Yeh, C. (2017), "Paci fi c-Basin Finance Journal Financial literacy, financial advisors , and information sources on demand for life insurance", Pacific-Basin Finance Journal, Vol. 43 March, pp. 218-237, Elsevier, doi: 10.1016/j.pacfin.2017.04.002.

Lusardi, A. and Mitchelli, O.S. (2007), "Financial literacy and retirement preparedness: evidence and implications for financial education”, Business Economics, Vol. 42 No. 1, pp. 35-44.

Lusardi, A. and Mitchell, O.S. (2017), "How ordinary consumers make complex economic decisions: financial literacy and retirement readiness", Quarterly Journal of Finance, Vol. 7 No. 03, p. 1750008.

Lusardi, A., Mitchell, O.S. and Mitchell, O.S. (2011), "Of pension economics and Finance: financial literacy and retirement planning in the United States *", pp. 509-525, doi: 10.1017/ S147474721100045X.

Luzolo, D.M. (2016), "Government intervention need for social security improvement in the Democratic Republic of the Congo A theoretical analysis using the principal - agent model Didier Mumpambala Luzolo *”, December, WIDER Working Paper 2016/165.

Meir, A.D.I., Mugerman, Y. and Sade, O. (2016), "Financial literacy and retirement planning: evidence from Israel", Vol. 14 No. 1, pp. 75-95.

Ntalianis, M. and Wise, V. (2011), "The role of financial education in retirement planning", Vol. 5 No. 2, pp. 23-37.

Risher, J. (2018), "When to use and how to report the results of PLS-SEM", April 2019, doi: 10.1108/ EBR-11-2018-0203.

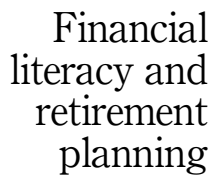

133

(1)


JBSED

1,2

Rooij, M.C.J.V., Lusardi, A. and Alessie, R.J.M. (2011), "Financial literacy and retirement planning in The Netherlands", Journal of Economic Psychology, Vol. 32 No. 4, pp. 593-608, Elsevier B.V., doi: 10.1016/j.joep.2011.02.004.

Safari, K. and Njoka, C. (2021), "Financial literacy and personal retirement planning among public sector employees in Bukavu city, the democratic republic of Congo", Vol. 23 No. 3, pp. 1-13, doi: 10.9790/487X-2303070113.

Satria, A. and Hutabarat, S. (2020), "Analysis the effect of financial literacy on financial planning for retirement (Case study lecturers and administrative staffs in universitas Indonesia)", Vol. 11 No. 5, pp. 741-750, doi: 10.34218/IJM.11.5.2020.066.

Sekita, S. (2015), "Of pension economics and Finance: financial literacy and retirement planning in Japan *”, October 2011, pp. 637-656, doi: 10.1017/S1474747211000527.

World Bank (2018), "Democratic republic of Congo systematic country diagnostic policy priorities for poverty reduction and shared prosperity in a post-conflict country and fragile state", Report No. 112733-ZR, (112733).

World Bank (2019), World Development Indicators.

\section{Further reading}

Larcker, C.F. (2016), "Evaluating structural equation models with unobservable variables and measurement”, Vol. 18 No. 1, pp. 39-50.

\section{Corresponding author}

Kulondwa Safari can be contacted at: kulsaf2@gmail.com

For instructions on how to order reprints of this article, please visit our website:

www.emeraldgrouppublishing.com/licensing/reprints.htm

Or contact us for further details: permissions@emeraldinsight.com 